\title{
ANALISIS HUBUNGAN TOTAL BAKTERI, BAHAN ORGANIK TERLARUT, NITRAT DAN FOSFAT DI PERAIRAN MOROSARI, DEMAK
}

Correlation Analysis of Total Bacteria, Dissolved Organic Matter, Nitrate and Phospate In Morosari, Demak

\author{
Rijal Galih Amta Nursubekhi, Niniek Widyorini*), Oktavianto Eko Jati \\ Program Studi Manajemen Sumberdaya Perairan, Departemen Sumberdaya Akuatik \\ Fakultas Perikanan dan Ilmu Kelautan, Universitas Diponegoro \\ Jl. Prof. Soedarto, SH, Tembalang, Semarang, Jawa Tengah - 50275, Telp/Fax. +6224 7474698 \\ Email : rijalgalih@yahoo.co.id
}

\begin{abstract}
ABSTRAK
Perairan Morosari terletak di wilayah Kabupaten Demak. Perairan ini telah banyak dimanfaatkan masyarakat sekitar untuk berbagai macam aktivitas seperti pembuangan limbah domestik maupun industri, jalur lalu lintas perahu nelayan, kawasan wisata dan kegiatan perikanan baik budidaya maupun tangkap. Limbah yang dibuang langsung ke perairan ini diperkirakan telah menyebabkan terjadinya peningkatan kandungan nutrien, seperti bahan organik, nitrat dan fosfat di perairan Morosari, Demak. Tujuan dari penelitian ini adalah untuk mengetahui kelimpahan total bakteri, bahan organik terlarut, nitrat, dan fosfat di Perairan Morosari, Demak. serta mengetahui hubungan antara total bakteri dengan bahan organik terlarut, nitrat dan fosfat di Perairan Morosari, Demak. Penelitian ini dilaksanakan pada bulan Mei 2018. Metode yang digunakan dalam penelitian ini adalah metode survei dan teknik pengambilan sampel menggunakan metode purposive sampling yang dilakukan pada lima stasiun. Hasil penelitian menunjukkan nilai total bakteri berkisar $<1 \times 10^{1}-3,6 \times 10^{11} \mathrm{CFU} / \mathrm{ml}$, bahan organik terlarut $12,77-33,81 \mathrm{mg} / \mathrm{l}$, nitrat 4,43 - 7,97 $\mathrm{mg} / \mathrm{l}$, fosfat $0,099-2,112 \mathrm{mg} / \mathrm{l}$.
\end{abstract}

Kata kunci: Total Bakteri, Bahan Organik Terlarut, Nitrat, Fosfat, Morosari

\section{ABSTRACT}

Morosari Waters is located in Demak Regency. This waters have been widely used by the surrounding community for various activities such as the disposal of domestic and industrial waste, fishing boat traffic lanes, tourist areas and fishing activities both aquaculture and capture. Waste that directly enters the water is thought to have caused an increase in nutrient content, such as organic matter, nitrate and phosphate in the waters of Morosari, Demak. The purpose of this study was to determine the total abundance of bacteria, dissolved organic matters, nitrate and phosphate in waters of Morosari, Demak. and knowing the relationship between total bacteria and dissolved organic matter, nitrate and phosphate in waters of Morosari, Demak. This research was carried out in May 2018. The method used in this research was survey method and the sampling technique used was purposive sampling method which was carried out at five stations. The results showed the total value of bacteria ranged from $<1 \times 10^{1}-3.6 x$ $10^{11} \mathrm{CFU} / \mathrm{ml}$, dissolved organic matter 12.77 - $33.81 \mathrm{mg} / \mathrm{l}$, nitrate 4.43 - $7.97 \mathrm{mg} / \mathrm{l}$, phosphate 0.099 $2,112 \mathrm{mg} / \mathrm{l}$.

Keywords: Total Bacteria, Dissolved organic matter, nitrate, Phosphate, Morosari.

*) Penulis penanggungjawab

\section{PENDAHULUAN}

Estuaria adalah suatu perairan semi tertutup yang berada di bagian hilir sungai dan masih berhubungan dengan laut, sehingga memungkinkan terjadinya percampuran antara air tawar dan air laut. Estuari merupakan daerah yang mempunyai sejumlah besar bahan organik, sejumlah besar organisme, dan produktivitas yang tinggi. Estuari berperan sebagai tempat penimbunan bahan-bahan organik yang di bawa oleh sungai atau dibawa masuk dari laut.

\footnotetext{
${ }^{\circledR}$ Copyright by Management of Aquatic Resources (MAQUARES)
} 
Perairan Morosari termasuk kawasan estuari yang merupakan area yang memiliki dinamika tinggi akibat dari adanya rob, dimana akan berpengaruh pada ketersediaan unsur hara yang ada di perairan tersebut. Unsur hara yang masuk ke dalam perairan juga berasal dari aliran air sungai yang masuk ke dalam badan perairan Morosari, Demak. Dalam hal ini, unsur hara sangat berperan penting terhadap kelangsungan hidup organisme didalamnya. Bakteri sebagai dekomposer bahan- bahan organik sangat berperan aktif untuk menyediakan zat- zat hara di perairan seperti bahanbahan organik (Kristiawan et al., 2014).

Keberadaan bakteri pada ekosistem perairan memiliki peran aktif sebagai dekomposer dalam proses mineralisasi bahan-bahan organik. Hasil mineralisasi dari proses tersebut adalah unsur-unsur hara yang esensial, merupakan sumber nutrisi bagi berbagai organisme. Oleh sebab itu, keterkaitan bakteri didalam ekosistem perairan laut terutama dalam penyedia unsur hara dapat digunakan sebagai indikator kesuburan perairan.

Aktivitas bakteri dalam siklus unsur hara adalah suatu hal yang tidak bisa dipisahkan. Bakteri pengurai sebagai agen utama dalam dekomposisi pada daerah estuari keberadaannya belum begitu banyak diteliti. Pemahaman yang baik dari keberadaan bakteri pengurai merupakan suatu hal yang bersifat eksplorasi untuk menemukan fungsi dan manfaatnya, sehingga dapat dijadikan informasi yang penting dalam pengelolaan daerah estuari yang berhubungan dengan bahan organik terlarut, nitrat dan fosfat. Menurut Wulandari et al. (2011), bakteri merupakan pemeran utama dalam dekomposisi bahan organik serta siklus daur ulang unsur kimia seperti karbon dan nitrogen yang diperlukan bagi kehidupan makhluk hidup. Semakin banyak unsur hara di dalam suatu perairan dapat menyebabkan suburnya perairan, akan tetapi jika terlalu tinggi kesuburannya akan menjadikan perairan itu tercemar. Oleh karena itu, pentingnya penelitian ini dilakukan.

\section{MATERI DAN METODE PENELITIAN}

\section{A. MATERI}

Materi yang digunakan dalam penelitian ini adalah sampel air yang diambil di lima titik perairan Morosari, Demak. Penelitian ini juga mengukur parameter fisika dan kimia lainnya berupa kandungan bahan organik, nitrat, fosfat, suhu air, kecerahan, kecepatan arus, salinitas, oksigen terlarut (DO) dan derajat keasaman (pH). Peralatan yang digunakan dalam penelitian ini antara lain Petri dish, bunsen, tabung reaksi, rak tabung reaksi, timbangan elektrik, inkubator, laminary airflow, hand counter, erlenmeyer, oven, mikrotip, panci, kompor, alumunium foil, termometer, pH paper, refraktometer, autoclave, hotplate magnetic strirrer, cool box, GPS, alat tulis dan kamera .

Bahan yang digunakan dalam penelitian ini adalah media agar Plate Count Agar (PCA) yang digunakan untuk menumbuhkan bakteri, akuades, sampel air dari perairan Morosari, Demak, larutan trisalt, butterfield's phosphot buffered (BFP) sebagai larutan pengencer, Triphenyl tetrazolium chloride berfungsi untuk memberi warna mikroorganisme, dan natrium oksalat, $\mathrm{H}_{2} \mathrm{SO}_{4}, \mathrm{KMnO}_{4}$ sebagai reagen uji.

\section{B. METODE}

Metode penelitian yang digunakan dalam penelitian ini yaitu metode survei. Metode survei adalah riset yang diadakan untuk memperoleh fakta - fakta tentang gejala atas permasalahan yang timbul. Metode survei dapat membantu untuk membandingkan kondisi - kondisi yang ada dengan kriteria yang telah ditentukan (Umar,2003).

Metode pengambilan sampel yang digunakan dalam penelitian ini yaitu purposive sampling. Penggunaan metode ini bertujuan untuk mendapatkan sampel yang sesuai dengan persyaratan atau tujuan peneliti sehingga diperoleh data yang akurat. Menurut Nasution (2003), pengambilan sampel yang dilakukan dengan teknik purposive sampling didasarkan pada pertimbangan peneliti yang mempertimbangkan unsur - unsur yang dikehendaki. Pengambilan sampel air menggunakan botol bakteri steril $125 \mathrm{ml}$ untuk total bakteri dan botol $600 \mathrm{ml}$ untuk bahan organik terlarut, nitrat dan fosfat. Pengambilan dilakukan dengan cara membuka botol sampel kemudian memasukkan kedalam perairan hingga terisi air sampel, lalu menutup botol sampel yang telah terisi sampel. Masukan botol sampel kedalam cool box. Pengambilan air sampel dilakukan tiga kali pengulangan dengan selang waktu seminggu pada setiap stasiun yang telah ditentukan Pengambilan sampel pada perairan Morosari dilakukan pada lima stasiun pengamatan. Stasiun satu merupakan daerah bagian akhir aliran muara Sungai Morosari dengan aktivitas manusia tinggi diharapkan banyak mengandung unsur hara tinggi. Stasiun dua, tiga, dan empat merupakan bagian perairan yang belum melebihi pasak batu atau titik pertemuan arus air tawar dan air laut dengan pengaruh gelombang lemah dan aktivitas manusia diharapkan mengandung unsur hara yang berbeda. Stasiun lima merupakan perairan laut dengan aktivitas manusia sedikit sehingga diharapkan memiliki kandungan yang berbeda dengan stasiun lainnya. Titik koordinat stasiun tersaji dalam Tabel 1 :

\footnotetext{
${ }^{\odot}$ Copyright by Management of Aquatic Resources (MAQUARES)
} 
Tabel 1. Titik Koordinat Penelitian Perairan Morosari, Demak

\begin{tabular}{ccc}
\hline \multirow{2}{*}{ Stasiun } & \multicolumn{3}{c}{ Titik Koordinat } \\
\cline { 2 - 3 } & Lintang Selatan & Bujur Timur \\
\hline 1 & $6^{\circ} 55^{\prime} 29,3^{\prime \prime} \mathrm{LS}$ & $110^{\circ} 28^{\prime} 48,8^{\prime \prime} \mathrm{BT}$ \\
2 & $6^{\circ} 55^{\prime}, 26,3^{\prime \prime} \mathrm{LS}$ & $110^{\circ} 28^{\prime} 48,4$ " BT \\
3 & $6^{\circ} 55^{\prime} 23,2^{\prime \prime} \mathrm{LS}$ & $110^{\circ} 28^{\prime} 48,6^{\prime \prime} \mathrm{BT}$ \\
4 & $6^{\circ} 55^{\prime} 22,9^{\prime \prime} \mathrm{LS}$ & $110^{\circ} 28^{\prime} 49,9^{\prime \prime} \mathrm{BT}$ \\
5 & $6^{\circ} 55^{\prime} 19,8^{\prime \prime} \mathrm{LS}$ & $110^{\circ} 28^{\prime} 48,0^{\prime \prime} \mathrm{BT}$ \\
\hline
\end{tabular}

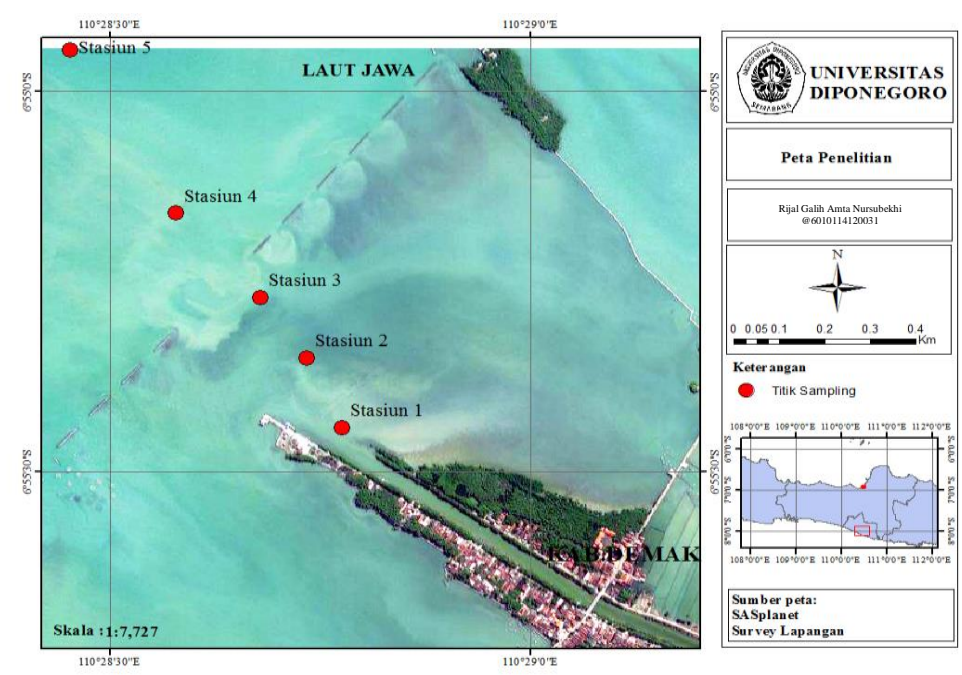

Gambar 1. Peta Lokasi Titik Pengambilan Sampel

Cara kerja untuk perhitungan bakteri sesuai dengan SNI No. 2332.3.2015 tentang cara uji mikrobiologi-bagian 3 : Penentuan angka lempeng total (ALT) sebagai berikut :

- Jumlah $1 \mathrm{ml}$ air sampel dimasukan kedalam tabung reaksi, setelah itu tambahkan $9 \mathrm{ml}$ larutan butterfield's phosphot buffered (BFP) homogenate tersebut merupakan seri pengenceran $10^{1}$;

- Pengenceran dilakukan kembali dan ditandai dengan seri $; 10^{2} ; 10^{3} ; 10^{4} ; 10^{5}$ menggunakan larutan pengencer berupa BFP dengan cara $1 \mathrm{ml}$ dari larutan homogenate $10^{1}$ dimasukkan ke $9 \mathrm{ml}$ BFP lalu digojog \pm 25 kali agar mendapatkan homogenate yang baik, untuk mendapatkan tingkat pengenceran $10^{2}$ dilakukan dengan cara yang sama sampai tingkat pengenceran terakhir;

- Platting dilakukan dengan cara setiap pengenceran diambil sebanyak $1 \mathrm{ml}$ menggunakan mikropipet, lalu platting ke dalam cawan petri steril dan dilakukan secara duplo;PCA yang sudah didinginkan dalam waterbath dan masih dalam kondisi hangat dimasukan ke cawan petri sebanyak $12 \mathrm{ml}-15 \mathrm{ml}$. Namun sebelum PCA dimasukkan ke dalam cawan petri, masukkan TTC : 2,3,5 - Triphenyl tetrazolium chloride sebanyak 1\% dari media PCA supaya mempermudah dalam proses perhitungan bakteri. Homogenate sampel dan media PCA agar tercampur sempurna lakukan pemutaran cawan ke depan ke belakang dan ke kiri ke kanan atau membentuk angka 8;

- Ditunggu sekitar 2-3 menit sehingga agar mengeras kemudian diinkubasi. Inkubasi dilakukan selama 48 jam dalam posisi petridish terbalik dengan suhu $35^{\circ} \mathrm{C}$.

Perhitungan koloni bakteri pada petri dish dapat dilakukan dengan membagi petri dish menjadi empat bagian dengan spidol yang tidak permanen. Hal ini dilakukan untuk memudahkan dalam perhitungan. Kemudian koloni bakteri yang telah terhitung ditandai dengan spidol. Petri dish yang dihitung adalah petri dish yang memiliki jumlah koloni bakteri 25 - 250 koloni bakteri. Hasil perhitungan jumlah koloni bakteri kemudian dimasukan ke dalam rumus :

$$
\mathrm{A}=\frac{1}{\text { Volumen inokulasi }} \times \sum \text { koloni } x \sum \text { Pengenceran }
$$

Metode yang digunakan dalam pengukuran berdasarkan SNI 06-6989.22-2004 yaitu pertama $10 \mathrm{ml}$ natrium oksalat $0,01 \mathrm{~N}$ dimasukkan ke dalam erlenmeyer $250 \mathrm{ml}$, lalu $5 \mathrm{ml} \mathrm{H}_{2} \mathrm{SO}_{4} 4 \mathrm{~N}$ dimasukkan dan dipanaskan dengan suhu $70^{\circ} \mathrm{C}$. Setelah itu diangkat dan dititrasi $\mathrm{KMnO}_{4} 0,01 \mathrm{~N}$ hingga berubah warna menjadi warna merah muda, dan dicatat berapa $\mathrm{ml}$ titrannya (a $\mathrm{ml})$.

\footnotetext{
${ }^{\odot}$ Copyright by Management of Aquatic Resources (MAQUARES)
} 
Tahap selanjutnya $50 \mathrm{ml}$ air sampel dimasukkan ke dalam Erlenmeyer, bila diduga bahan organik yang terdapat pada sampel tinggi maka perlu melakukan pengenceran dengan cara mengambil $10 \mathrm{ml}$ sampel air dan ditambahkan $40 \mathrm{ml}$ akuades. Setelah itu $5 \mathrm{ml} \mathrm{H}_{2} \mathrm{SO}_{4} 4 \mathrm{~N}$ ditambahkan. Lalu "a" ml 0,01 $\mathrm{N} \mathrm{KMnO}_{4}$ ditambahkan dari buret dan selama 10 menit didihkan dengan suhu $70^{\circ} \mathrm{C}$ kemudian diangkat. Bila suhunya turun menjadi $60^{\circ} \mathrm{C}$, langsung ditambahkan Natrium Oksalat $0,01 \mathrm{~N}$ sampai berubah warna menjadi merah jambu atau pink dan dicatat berapa $\mathrm{ml}$ titrannya (x ml). Selanjutnya mengambil $50 \mathrm{ml}$ akuades, dan prosedur yang sama dilakukan seperti perlakuan pada sampel air, dan dicatat berapa $\mathrm{ml}$ titrannya $(\mathrm{Y} \mathrm{ml})$. Rumus untuk menghitung bahan organik total dalam metode TOM menurut SNI 06-6989.22-2004 :

$$
\operatorname{TOM}(\mathrm{mg} / \mathrm{l})=\frac{(X-Y) \times 31,6 \times 0,01 \times 1000}{m l \text { sampel }}
$$

Analisis kandungan nitrat dilakukan sesuai prosedur metode uji APHA 2012, Section 4500-NO3 yaitu dengan mengambil sampel uji sebanyak 50,0 mL; kemudian memasukkan sampel ke dalam erlenmeyer $100 \mathrm{~mL}$; menambahkan $1 \mathrm{~mL}$ HCL $1 \mathrm{~N}$; menguji sampel. Membaca absorbansi panjang gelombang $220 \mathrm{~nm}$ dan $275 \mathrm{~nm}$ pada masing-masing sampel.

Dilakukan sesuai prosedur metode uji APHA 2012, Section 4500 PB.5 \& 4500-PD yaitu : pipet $50 \mathrm{~mL}$ sampel uji secara duplo dan dimasukkan masing-masing kedalam erlenmeyer; tambahkan 1 tetes indikator fenolftalin. Jika terbentuk warna merah muda, ditambahkan tetes demi tetes larutan $\mathrm{H}_{2} \mathrm{SO}_{4}$ 1:3 sampai warna hilang; ditambahkan 1 ml larutan $\mathrm{H}_{2} \mathrm{SO}_{4}$ 1:3. Tambahkan $+0,4$ gram kristal Ammonium Persulfat $\left(\mathrm{NH}_{4}\right)_{2} \mathrm{~S}_{2} \mathrm{O}_{8}$ atau $+0,5$ gram Potasium Persulfat $\left(\mathrm{K}_{2} \mathrm{~S}_{2} \mathrm{O}_{8}\right)$. Kemudian dipanaskan dengan hotplate selama 30 - 40 menit atau sampai volume $10 \mathrm{ml}$; biarkan dingin, setelah dingin ditambahkan $30 \mathrm{ml}$ air suling dan $0,05 \mathrm{ml}$ (1 tetes) Phenolphthalein. Ditambahkan 4,0 ml Ammonium Molybdate reagent I dan 0,5 ml (3-10 tetes) Larutan Stannous Chlorida reagen I. Baca absorbansi dan konsentrasinya, pada alat spektrofotometer pada panjang gelombang 702,8 nm dalam kisaran waktu antara 10 menit sampai 12 menit.

\section{Analisis Citra Satelit}

Analisis citra satelit terdapat pengolahan data terdiri dari 2 tahapan yang mencakup pengolahan informasi dengan menggunakan software Ms. Excel dan analisis data menggunakan software ArcGIS 10.3. Adapun metodenya yang pertama membuka aplikasi ArcGIS 10.3. Setelah itu memasukan peta lokasi yang diperoleh dari SASPlanet yang sudah didigitasi dengan software ArcGIS 10.3 sehingga diperoleh peta digital yang memiliki koordinat. Selanjutnya melakukan add table berdasarkan data yang telah diolah dengan Ms. Excel pada program ArcView GIS 10.3. Setelah itu melakukan proses interpolasi data dengan teknik IDW. Interpolasi dengan IDW (Inverse Distance Weighted) digunakan untuk menginterpolasi peta yang memperlihatkan pola persebaran suatu obyek yang diamati. Tahap terakhir yaitu layout, dimana dapat dilihat sebaran total bakteri, bahan organik terlarut, nitrat dan fosfat berdasarkan warna (Sudarwin, 2008).

\section{Analisis Data}

Setelah mendapatkan data, selanjutnya dilakukan uji statistik korelasi untuk melihat hubungan antara total bakteri dengan kandungan total bahan organik terlarut, nitrat, dan fosfat, dimana total bakteri sebagai variabel independent dan total bahan organik terlarut, nitrat serta fosfat sebagai variabel dependent. Analisis ini digunakan untuk mencari hubungan antar variabel. Menurut Hartono (2008) bahwa hasil analisis dari korelasi adalah koefisien yang menunjukkan kekuatan dan kelemahan dari suatu hubungan. Pengolahan data menggunakan aplikasi SPSS (Statistical Package for Social Science).

$\mathrm{H}_{0}$ : Tidak terdapat hubungan antara jumlah total bakteri dengan bahan organik, nitrat dan fosfat di perairan

$\mathrm{H}_{1}$ : Terdapat hubungan antara jumlah total bakteri dengan bahan organik, nitrat dan fosfat di perairan

Pengambilan keputusan didasarkan pada hasil perhitungan. $\mathrm{H}_{0}$ diterima apabila probabilitas $>0,05$ maka tidak terdapat korelasi antara jumlah bakteri dengan bahan organik, nitrat dan fosfat di perairan Morosari, Demak, dan jika $\mathrm{H}_{1}$ diterima atau $\mathrm{H}_{0}$ ditolak probabilitas $<0,05$ maka terdapat korelasi antara jumlah bakteri dengan bahan organik, nitrat dan fosfat di perairan Morosari, Demak.

Menurut Sugiyono (2007), untuk mengetahui korelasi antara dua variabel maka diperlukan pengujian (r) dengan kriteria sebagai berikut:

$\mathrm{r}=0$ maka tidak memiliki korelasi

$0<\mathrm{r} \leq 0,19$ maka memiliki korelasi sangat rendah (lemah sekali)

$0,2<\mathrm{r} \leq 0,39$ maka memiliki korelasi lemah

$0,4<\mathrm{r} \leq 0,69$ maka memiliki korelasi cukup

$0,7<\mathrm{r} \leq 0,89$ maka memiliki korelasi tinggi

$0,9<\mathrm{r} \leq 1$ maka memiliki korelasi sangat tinggi dan kuat

$\mathrm{r}=1$ maka memiliki korelasi sempurna. 
3. HASIL DAN PEMBAHASAN

Penghitungan Total Coliform dan Parameter Kualitas Perairan

Tabel 2. Hasil Perhitungan Total Bakteri (Cfu/ml) di Perairan Morosari, Demak

\begin{tabular}{cccccc}
\hline Stasiun & Ulangan 1 & Ulangan 2 & Ulangan 3 & Rata - rata & Simpangan Baku \\
\hline 1 & $4,6 \times 10^{2}$ & $1,0 \times 10^{2}$ & $2,5 \times 10^{2}$ & $2,73 \times 10^{2}$ & $8,0 \times 10^{4}$ \\
2 & $3,6 \times 10^{11}$ & $1,2 \times 10^{2}$ & $0,1 \times 10^{2}$ & $1,2 \times 10^{11}$ & $6,48 \times 10^{22}$ \\
3 & $9,5 \times 10^{2}$ & $0,8 \times 10^{2}$ & $<1 \times 10^{1}$ & $3,48 \times 10^{2}$ & $4,25 \times 10^{5}$ \\
4 & $8,0 \times 10^{2}$ & $0,3 \times 10^{2}$ & $0,4 \times 10^{2}$ & $2,88 \times 10^{2}$ & $2,18 \times 10^{2}$ \\
5 & $1,0 \times 10^{8}$ & $2,9 \times 10^{3}$ & $0,2 \times 10^{2}$ & $3,3 \times 10^{7}$ & $5,0 \times 10^{15}$ \\
\hline
\end{tabular}

Sumber: Hasil Sampel Analisis Laboratorium Kesehatan Kota Semarang, Jawa Tengah 2018.

Berdasarkan Tabel 2 dapat dilihat bahwa jumlah total bakteri yang diperoleh sangat bervariasi. Kelimpahan total bakteri pada stasiun satu berkisar antara $100-4,6 \times 10^{2} \mathrm{CFU} / \mathrm{ml}$. Stasiun dua memiliki nilai total bakteri paling tinggi diantara stasiun lain yaitu berkisar $10-3,6 \times 10^{11} \mathrm{CFU} / \mathrm{ml}$. Stasiun tiga memiliki nilai total bakteri paling rendah dari staiusn lain yaitu berkisar $<1 \times 10^{1}-955 \mathrm{CFU} / \mathrm{ml}$. Pada stasiun empat nilai total bakteri berkisar $30-8,0 \times 10^{2}$ $\mathrm{CFU} / \mathrm{ml}$. Stasiun lima memiliki nilai berkisar antara $15-1,0$ x $10^{8} \mathrm{CFU} / \mathrm{ml}$.

Tabel 3. Hasil Perhitungan Kandungan Total Bahan Organik Terlarut, Nitrat dan Fosfat di Perairan Morosari, Demak

\begin{tabular}{cccccc}
\hline Variabel & Stasiun & Ulangan 1 & Ulangan 2 & Ulangan 3 & Rata - rata \\
\hline Bahan & 1 & 22,56 & 19,02 & 22,15 & 21,24 \\
Organik & 2 & 23 & 28,69 & 12,77 & 21,49 \\
Terlarut & 3 & 25 & 33,81 & 17,89 & 25,57 \\
(mg/l) & 4 & 19,59 & 32,67 & 19,59 & 23,95 \\
& 5 & 28,69 & 28,12 & 12,89 & 23,23 \\
& & & & & 6,79 \\
Nitrat (mg/l) & 1 & 7,53 & 4,87 & 7,97 & 5,46 \\
& 2 & 4,87 & 5,31 & 6,20 & 5,02 \\
& 3 & 5,31 & 4,43 & 5,31 & 5,02 \\
& 5 & 5,76 & 4,43 & 4,87 & \\
& & 4,43 & 6,20 & 5,76 & 0,11 \\
Fosfat (mg/l) & 1 & 2,112 & 0,370 & 0,845 & 0,47 \\
& 2 & 0,366 & 1,300 & 0,236 & 0,37 \\
& 3 & 0,480 & 0,629 & 0,291 & 0,28
\end{tabular}

Sumber: Laboratorium Kesehatan Kota Semarang, Jawa Tengah 2018.

Berdasarkan Tabel 3 dapat dilihat bahwa pada perairan Morosari, Demak jumlah total bahan organik terlarut, nitrat, dan fosfat yang diperoleh sangat bervariasi. Nilai total bahan organik terlarut antara 21,24-25,57 mg/l. untuk nilai nitrat yaitu antara 5,02-6,79 mg/l, sedangkan nilai fosfat adalah $0,28-1,11 \mathrm{mg} / \mathrm{l}$.

Tabel 4. Hasil Pengukuran Parameter Kualitas Perairan di Perairan Morosari, Demak

\begin{tabular}{cccccccc}
\hline \multirow{2}{*}{$\begin{array}{c}\text { Sam- } \\
\text { pling }\end{array}$} & $\begin{array}{c}\text { Sta- } \\
\text { siun }\end{array}$ & $\begin{array}{c}\text { Temperatur } \\
\text { Air }\left({ }^{\circ} \mathrm{C}\right)\end{array}$ & $\mathrm{pH}$ & Salinitas $(\%)$ & DO (mg/l) & $\begin{array}{c}\text { Kec. Arus } \\
(\mathrm{m} / \mathrm{s})\end{array}$ & Kecerahan \\
\hline \multirow{4}{*}{} & 1 & 29 & 6 & 35 & 4,16 & 0,11 & 13 \\
$\mathrm{I}$ & 2 & 31 & 7 & 35 & 4 & 0,10 & 17 \\
& 3 & 31 & 7 & 35 & 5,8 & 0,09 & 10 \\
& 4 & 31 & 7 & 35 & 5,6 & 0,07 & 22 \\
& 5 & 31 & 6 & 35 & 6,4 & 0,05 & 25 \\
\hline
\end{tabular}

${ }^{\odot}$ Copyright by Management of Aquatic Resources (MAQUARES) 
Analisis Hubungan Total Bakteri, Bahan Organik Terlarut, Nitrat Dan Fosfat Di Perairan Morosari

\begin{tabular}{cccccccc}
\hline \multirow{2}{*}{$\begin{array}{c}\text { Sam- } \\
\text { pling }\end{array}$} & $\begin{array}{c}\text { Sta- } \\
\text { siun }\end{array}$ & $\begin{array}{c}\text { Temperatur } \\
\text { Air }\left({ }^{\circ} \mathrm{C}\right)\end{array}$ & $\mathrm{pH}$ & Salinitas $(\%)$ & DO (mg/l) & $\begin{array}{c}\text { Kec. Arus } \\
(\mathrm{m} / \mathrm{s})\end{array}$ & Kecerahan \\
\hline \multirow{4}{*}{ II } & 1 & 28 & 8 & 32 & 4,8 & 0,23 & 21 \\
& 2 & 29 & 7 & 32 & 3,8 & 0,21 & 20 \\
& 3 & 29 & 7 & 33 & 4 & 0,16 & 18 \\
& 4 & 29 & 8 & 33 & 5,2 & 0,17 & 17 \\
& 5 & 30 & 7 & 33 & 5 & 0,16 & 29 \\
\hline \multirow{4}{*}{ III } & 1 & 30 & 7 & 30 & 4 & 0,23 & 35 \\
& 2 & 31 & 8 & 33 & 7,2 & 0,15 & 20 \\
& 4 & 29 & 7 & 32 & 6,8 & 0,17 & 26 \\
& 5 & 28 & 8 & 34 & 5,6 & 0,19 & 30 \\
\hline
\end{tabular}

Berdasarkan Tabel 3 dapat dilihat bahwa kisaran temperatur air yang didapat di perairan Morosari, Demak sebesar $28-31^{\circ} \mathrm{C}$. Besarnya nilai $\mathrm{pH}$ berkisar antara $6-8$. Kadar salinitas yang diperoleh tidak bervariasi, hanya berkisar antara $30-35 \%$. Kandungan oksigen terlarut yang diperoleh pada sampel air berkisar antara 3,8 - 7,2 mg/l, kecepatan arus sebesar $0,04-0,23 \mathrm{~m} / \mathrm{s}$, kecerahan $10-41 \mathrm{~cm}$.

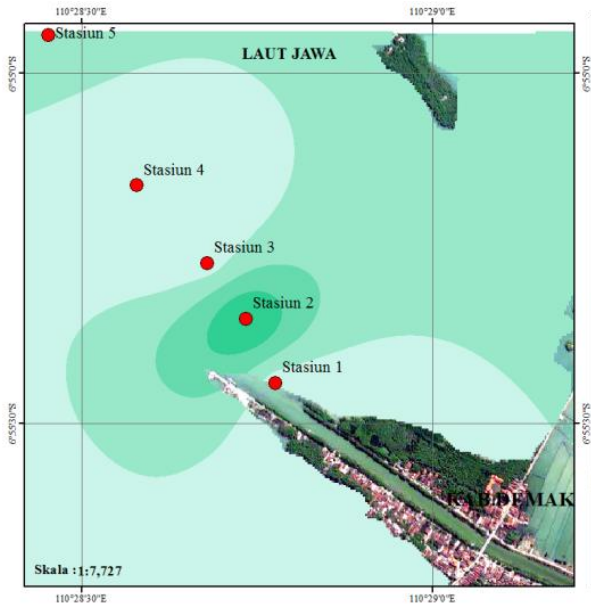

Gambar 2. Peta Persebaran Total Bakteri di Perairan Morosari, Demak

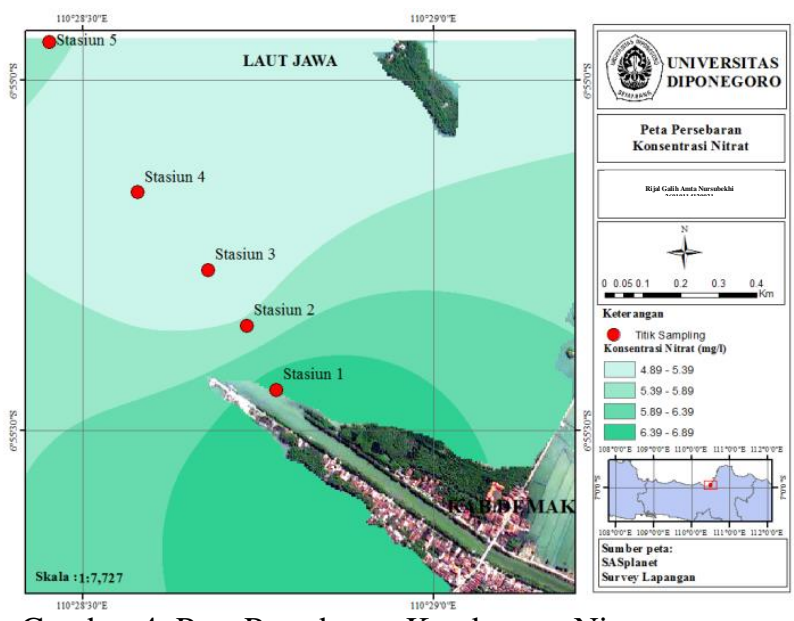

Gambar 4. Peta Persebaran Kandungan Nitrat di Perairan Morosari, Demak
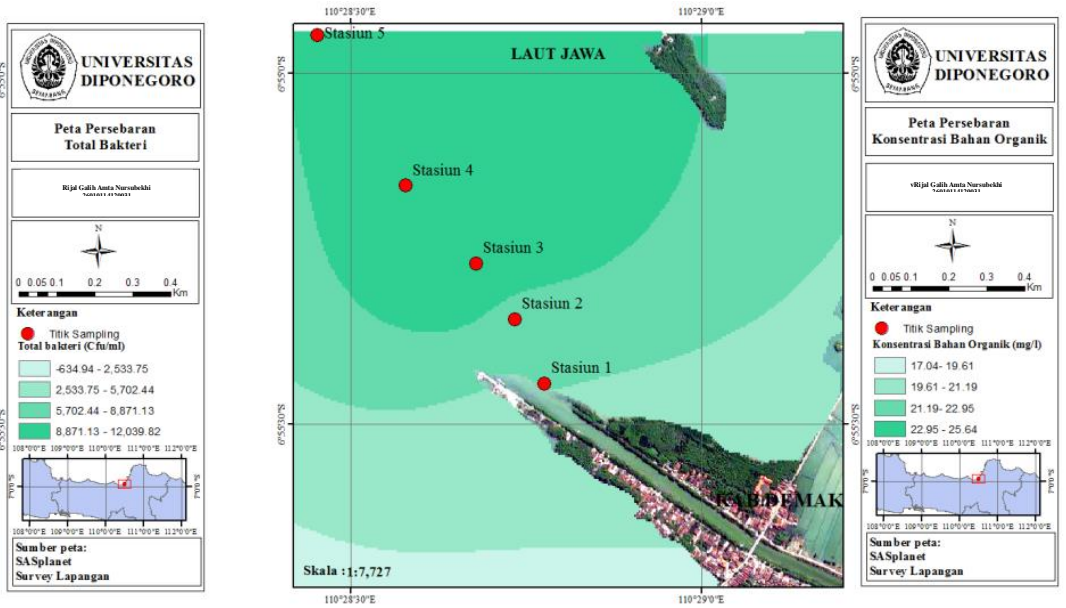

Gambar 3. Peta Persebaran Total Bahan Organik Terlarut di Perairan Morosari, Demak
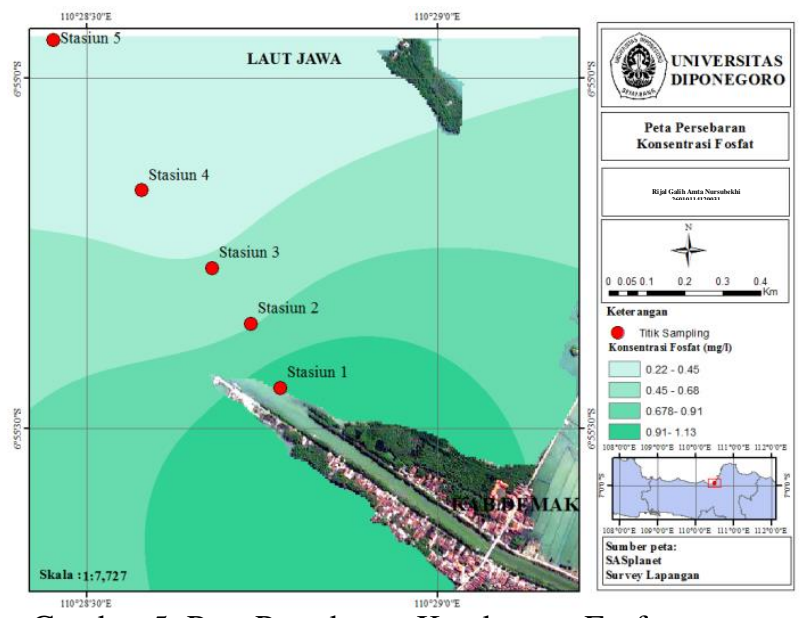

Gambar 5. Peta Persebaran Kandungan Fosfat di Perairan Morosari, Demak

Tabel 5. Analisis Uji Korelasi Total Bakteri dengan Total Bahan Organik Terlarut 


\begin{tabular}{ll|ccc}
\hline & & Total Bahan Organik Terlarut & Nitrat & Fosfat \\
\hline \multirow{3}{*}{ Total Bakteri } & Pearson Corelation & 0,272 & $-0,238$ & 0,035 \\
& Sig. (2-tailed) & 0,326 & 0,394 & 0,901 \\
& & & & 15 \\
\hline
\end{tabular}

\section{Pembahasan}

\section{Total Bakteri}

Total bakteri yang ada di perairan Morosari Kabupaten Demak menunjukan hasil yang dimana memiliki nilai berkisar antara $<1 \times 10^{1}-3,6 \times 10^{11} \mathrm{CFU} / \mathrm{ml}$. Angka total bakteri tersebut termasuk tinggi. Tingginya nilai tersebut dipengaruhi oleh beberapa faktor yang terdapat di perairan. Faktor aktivitas manusia pada perairan salah satu contohnya nelayan dalam melakukan kegiatan penangkapan, yang artinya terdapat kegiatan manusia yang secara langsung memberikan dampak bagi perairan ini sehingga kandungan bakteri di lokasi ini tinggi. Hasil kisaran nilai total bakteri pada pengulangan pertama lebih tinggi dari pengulangan kedua. Hal ini dikarenakan pada saat sebelum pengambilan sempel pengulangan kedua terjadi turun hujan. Perubahan temperatur menyebabkan terganggunya proses yang terjadi di mikroorganisme. Hal ini dipengaruhi oleh Askari (2010), temperatur memiliki pengaruh terhadap semua proses yang terjadi didalam mikroorganisme.

Bakteri juga dapat digunakan sebagai bioindikator kesuburan suatu perairan. Hal ini karena kandungan biomasa bakteri di perairan merupakan konversi produktivitas bakteri yang sangat penting sebagai penyedia unsur karbon. Menurut Maranon et al. (2005) menyatakan bahwa bila produktivitas bakteri tinggi maka dapat dikatagorikan tingkat kesuburan suatu perairan akan semakin baik. Namun demikian kriteria tingkat kesuburan untuk ekosistem perairan estuari tropikal belum ada terutama di perairan Indonesia. Nilai total bakteri yang diperoleh pada Perairan Morosari, Demak termasuk tinggi. Berdasarkan hasil tersebut Perairan Morosari, Demak dikategorikan berproduktivitas subur, hal ini terindikasi dengan jumlah kandungan bakteri produktivitinya yang tinggi.

\section{Kandungan Bahan Organik}

Perhitungan kadar bahan organik pada sampel air menunjukkan bahwa kadar bahan organik pada perairan Morosari, Demak sangat bervariasi. Kadar bahan organik terendah yaitu $12,77 \mathrm{mg} / \mathrm{l}$ pada stasiun dua pengulangan ketiga, sedangkan kadar bahan organik tertinggi yaitu $33,81 \mathrm{mg} / \mathrm{l}$ pada stasiun tiga pengulangan kedua. Stasiun tiga memiliki nilai kisaran yang cukup tinggi dari stasiun lain yaitu 17,89-33,81 mg/l, dimana hal ini dapat diliat dari nilai DO yang cukup rendah. Angka kadar bahan organik terlarut tersebut cukup tinggi dan melebihi baku yang ada pada Keputusan Menteri Negara Lingkungan Hidup Nomor 51 Tahun 2004 tentang Baku Mutu Air Laut sebesar 20 mg/l. Bahan organik pada pengulangan ketiga memiliki nilai yang rendah, penurunan nilai bahan organik pada pengulangan ketiga diduga karena adanya kenaikan konsentrasi $\mathrm{O}_{2}$ akibat air hujan yang masuk ke perairan. Hal ini dapat dilihat dari nilai konsentrasi DO yang meningkat pada pengulangan ketiga dibandingkan dengan pengulangan kedua. Sesuai Supriyantini et al. (2017) bahwa dekomposer memerlukan $\mathrm{O}_{2}$ dalam menguraikan bahan organik, sehingga dengan meningkatnya $\mathrm{O}_{2}$ maka dapat memaksimalkan kinerja dari dekomposer dalam penguraian bahan organik.

\section{Kandungan Nitrat}

Konsentrasi nitrat yang didapatkan pada perairan Morosari, Demak berkisar antara 4,43 hingga 7,97 mg/l. Angka konsentrasi nitrat tersebut sangat tinggi dan melebihi baku mutu air laut untuk wisata bahari yang telah ditetapkan pada Keputusan Menteri Negara Lingkungan Hidup Nomor 51 Tahun 2004 tentang Baku Mutu Air Laut sebesar $0,008 \mathrm{mg} / \mathrm{l}$. Tingginya konsentrasi nitrat yang terkandung pada sampel air perairan Morosari, Demak kemungkinan besar dipengaruhi oleh masukan massa air Sungai Sayung yang membawa masukan limbah yang berasal dari daratan. Hal ini diperkuat oleh Mustofa (2015), yang menyatakan bahwa nitrat merupakan bentuk nitrogen utama di perairan alami yang berasal dari ammonium yang masuk ke dalam badan sungai terutama melalui limbah domestik. Senyawa nitrat secara alami dapat berasal dari buangan limbah baik limbah daratan seperti domesik, pertanian dan limbah peternakan ataupun sisa pakan yang dengan adanya bakteri dapat terurai menjadi zat hara.

\section{Kandungan Fosfat}

Konsentrasi fosfat yang didapat pada perairan Morosari, Demak memiliki nilai yang sangat bervariaif. Nilai fosfat terendah yang diperoleh yaitu $0,099 \mathrm{mg} / \mathrm{l}$ pada stasiun lima pengulangan ketiga. Nilai fosfat tertinggi yaitu 2,112 $\mathrm{mg} / \mathrm{l}$ pada stasiun satu pengulangan pertama. Tingginya nilai fosfat pada stasiun satu menunjukan adanya buangan limbah yang tinggi dari Wisata Bahari Morosari dan juga buangan limbah rumah tangga dari muara sungai. Kadar fosfat menurut EPA (2008) adalah $<0,048 \mathrm{mg} / \mathrm{l}$ tergolong rendah, antara 0,048-0,096 mg/l tergolong sedang,

\footnotetext{
${ }^{\odot}$ Copyright by Management of Aquatic Resources (MAQUARES)
} 
dan >0,096 mg/l tergolong tinggi. Berdasarkan hal tersebut kadar fosfat pada perairan Morosari, Demak tergolong berlebih dan dapat memicu timbulnya eutrofikasi.

\section{Hubungan Total Bakteri Dengan Bahan Organik Terlarut, Nitrat dan Fosfat}

Hasil yang diperoleh dari analisis korelasi Pearson terhadap total bakteri dengan total bahan organik terlarut diperoleh nilai korelasi sebesar 0,272 yang menunjukan hubungan antara total bakteri dengan total bahan organik terlarut lemah atau tidak terlalu erat (sig. > 0,05). Hal ini diperkuat oleh Siagan dan Sugiarto (2000), nilai koefisien korelasi antara 0,1 - 0,5 menunjukan hubungan langsung yang lemah. Sehingga adanya bahan organik akan memicu munculnya bakteri. Sehingga kandungan bahan organik berhubungan dengan keberadaan bakteri (Effendi,2003).

Hasil yang diperoleh dari analisis uji korelasi Pearson antara total bakteri dengan kadar nitrat diperoleh nilai korelasi sebesar -0,238 yang menunjukan hubungan berbanding terbalik antara total bakteri dengan nitrat yang lemah atau tidak terlalu erat (sig. > 0,05). Menurut Young (1982) dalam Wibisono (2002), nilai koefisien korelasi antara 0,1 - 05 menunjukan hubungan lemah. Nilai korelasi yang berbanding terbalik dimana total bakteri yang tinggi tidak diikuti dengan kadar nitrat yang tinggi. Hal tersebut terjadi karena variabel yang diteliti adalah total bakteri bukan bakteri yang spesifik. Sehingga total bakteri yang tinggi tidak diikuti dengan kadar nitrat yang tinggi pula.

Hasil yang diperoleh dari analisis uji korelasi Pearson terhadap total bakteri dengan kadar fosfat diperoleh nilai korelasi sebesar 0,035 yang menunjukan tidak terdapat korelasi antara total bakteri dengan kadar fosfat di perairan (sig. > 0,05). Menurut Siagan dan Sugiarto (2000), nilai koefisien antara 0,1 - 0,5 menunjukan hubungan korelasi yang rendah. Hal ini dapat dilihat dari rata-rata jumlah total bakteri tertinggi pada stasiun dua, namun rata-rata kadar fosfat tertinggi berada pada stasiun satu. Dari hal tersebut dapat disimpulkan bahwwa kadar fosfat pada perairan tidak berhubungan langsung dengan total bakteri yang ada, tetapi fosfat lebih berhubungan dengan tingkat kesuburan perairan.

\section{KESIMPULAN}

Kesimpulan yang dapat diperoleh dari penelitian yang telah dilakukan adalah sebagai berikut :

1. Hasil penelitian yang diperoleh di perairan Morosari, Demak menunjukkan bahwa nilai total bakteri berkisar $<1$ x $101-3,6$ x $1011 \mathrm{CFU} / \mathrm{ml}$, bahan organik terlarut $12,77-33,81 \mathrm{mg} / \mathrm{l}$, nitrat 4,43 - 7,97 mg/l, fosfat 0,099 $2,112 \mathrm{mg} / \mathrm{l}$.

2. Tidak terdapat hubungan yang signifikan antara total bakteri dengan bahan organik terlarut, nitrat, dan fosfat di perairan Morosari, Demak.

3. Perairan Morosari, Demak termasuk perairan hipertrofik.

\section{UCAPAN TERIMA KASIH}

Penulis mengucapkan terima kasih kepada semua pihak yang telah memberikan bantuan, masukan dan saran dalam pembuatan jurnal ini. Terima kasih pula kepada Dr. Ir. Max R. Muskananfola, M.Sc dan Arif Rahman, S.Pi., M.Si yang turut meberikan masukan dan saran dalam pembuatan jurnal ini

\section{DAFTAR PUSTAKA}

Kristiawan D., Niniek W. dan Haeruddin. 2014. Hubungan Total Bakteri dengan Kandungan Bahan Organik Total di Muara Kali Wiso, Jepara. DIPONEGORO JOURNAL OF MAQUARES, 3(4) : 24-33

Kunarso, D.H dan Titiek, I.A. 2012. Kajian Bakteri Heterotropik di Perairan Laut Lamalera. Jurnal Ilmu Kelautan Undip. 17 (2) : 63-73.

Nasution. 2003. Metode Penelitian Naturalistik Kualitatif. Bandung: Tarsito. 84 hlm.

Umar, H. 2003. Metode Riset Bisnis Panduan Untuk Melakukan Riset. Gramedia, Jakarta, 45 hlm.

Sudarwin, 2008, Analisis Spasial Pencemaran Logam Berat (Pb Dan Cd) Pada Sedimen Aliran Sungai Dari Tempat Pembuangan Akhir (TPA) Sampah Jatibarang Semarang. [Tesis]. Program Pasca Sarjana Universitas Diponegoro, Semarang. $33 \mathrm{hlm}$.

Hartono, J. 2008. Teori Portofolio dan Analisis Investasi. BPFE, Yogyakarta. $44 \mathrm{hlm}$.

Sugiyono. 2007. Metode Penelitian Kuantitatif Kualitatif dan R dan D. Alfabeta, Bandung. $330 \mathrm{hlm}$.

Askari. 2010. Dasar - Dasar Hortikultura. Departemen Budidaya Pertanian. Fakultas Pertanian. IPB. 505 hlm.

Maranon, E., Cermeno P., dan Perez, V. 2005. Continuity In The Photosynthetic Production Of Dissolved Organic Carbon From Eutrophic to Oligotrophic Waters. Mar. Ecol. Prog. Ser., 299: 7 - 17.

Mustofa, A. 2015. Kandungan Nitrat dan Pospat sebagai Faktor Tingkat Kesuburan Perairan Pantai. Jurnal DISPROTEK., 6 (1): 13 - 19

US EPA [United States Environmental Protection Agency]. 2008. Final Total Maximum Daily Load (TMDL) for Organic Enrichment \& Dissolved oxygen. Georgia: US EPA Region 4.

Siagan, D dan Sugiarto. 2000. Metode Statistika Untuk Ekonomi dan Bisnis. Gramedia. Jakarta.

\footnotetext{
${ }^{\odot}$ Copyright by Management of Aquatic Resources (MAQUARES)
} 